\title{
Mucosa-associated lymphoid tissue lymphoma of the trachea: case report
}

\author{
Linfoma do tecido linfoide associado à mucosa de traqueia: relato de caso
}

\author{
Maria Elisa Ruffolo Magliari', Renata Telles Rudge de Aquino", Anna Luiza Lobão Gonçalves"', Fábio Marionilv, Fabíola \\ del Carlo Bernardiv , Sérgio Brasilv", Joaquim Antonio da Fonseca Almeida ", Benedito Juarez Andrade ${ }^{\mathrm{VIII}}$, Carlos Sérgio \\ Chiattone ${ }^{1 \mathrm{x}}$, Carlos Alberto da Conceição Lima ${ }^{\mathrm{X}}$
}

Faculdade de Ciências Médicas da Santa Casa de São Paulo (FCMSCSP), São Paulo, Brazil

\author{
'MD, MSc. Instructor Professor, Discipline of Internal \\ Medicine, Department of Clinical Medicine, \\ Faculdade de Ciências Médicas da Santa Casa de \\ São Paulo (FCMSCSP), São Paulo, Brazil. \\ "MD, PhD. Assistant Professor, Discipline of Internal \\ Medicine, Department of Clinical Medicine, \\ Faculdade de Ciências Médicas da Santa Casa de \\ São Paulo (FCMSCSP), São Paulo, Brazil. \\ "Undergraduate Student, Faculdade de Ciências \\ Médicas da Santa Casa de São Paulo (FCMSCSP), São \\ Paulo, Brazil. \\ "MD. First Attending Physician, Peroral Endoscopy \\ Service, Irmandade da Santa Casa de Misericórdia \\ de São Paulo, São Paulo, Brazil. \\ vMD, PhD. Assistant Professor, Discipline of \\ Pathologic Anatomy, Department of Pathological \\ Anatomy, Faculdade de Ciências Médicas da Santa \\ Casa de São Paulo (FCMSCSP), São Paulo, Brazil. \\ "MD, MSc. Second Attending Physician, Discipline \\ of Hematology, Irmandade da Santa Casa de \\ Misericórdia de São Paulo, São Paulo, Brazil. \\ vi'MD. Instructor Professor, Discipline of Internal \\ Medicine, Department of Clinical Medicine, \\ Faculdade de Ciências Médicas da Santa Casa de \\ São Paulo (FCMSCSP), São Paulo, Brazil. \\ "IIMD. First Attending Physician, Imaging Diagnostics \\ Service, Irmandade da Santa Casa de São Paulo, São \\ Paulo, Brazil. \\ ${ }^{1} \mathrm{MD}$, PhD. Adjunct Professor, Discipline of \\ Hematology, Department of Clinical Medicine, \\ Faculdade de Ciências Médicas da Santa Casa de \\ São Paulo (FCMSCSP), São Paulo, Brazil. \\ ${ }^{x} \mathrm{MD}$, PhD. Adjunct Professor, Discipline of Internal \\ Medicine, Department of Clinical Medicine, \\ Faculdade de Ciências Médicas da Santa Casa de \\ São Paulo, São Paulo, Brazil.

\section{KEY WORDS} \\ Lymphoma, B-Cell, marginal zone. \\ Neoplasms. \\ Tracheal neoplasms. \\ Lymphoma. \\ Lymphoma, non-Hodgkin.
}

\section{PALAVRAS-CHAVE:}

Linfoma de zona marginal tipo células $B$.

Neoplasias.

Neoplasias da traquéia.

Linfoma.

Linfoma não Hodgkin.

\begin{abstract}
CONTEXT: Mucosa-associated lymphoid tissue (MALT) lymphomas are most commonly found in the stomach, lungs, orbital soft tissue, salivary glands and thyroid. Involvement of the trachea is extremely rare. CASE REPORT: This report describes a rare case of MALT lymphoma of the trachea in a 71-yearold woman who presented with a one-year history of coughing, dyspnea, hoarseness and weight loss. There was an infiltrative lesion in the mid-trachea. The anatomopathological diagnosis was only made from the fifth endoscopic biopsy attempt. Immunochemotherapy consisting of rituximab, cyclophosphamide, vincristine and prednisone (R-COP) induced complete remission of the symptoms and endoscopic lesion.

CONCLUSIONS: MALT Iymphoma of the trachea is extremely rare and indolent disease. It has to be considered in the differential diagnosis of airway lesions. It is crucial to obtain an anatomopathological diagnosis from a specialized pathologist. Immunochemotherapy with R-COP induced complete remission of the disease.
\end{abstract}

\section{RESUMO}

CONTEXTO: Linfomas de tecido linfoide associado à mucosa (TLAM) são mais comumente encontrados no estômago, pulmões, órbita, glandulas salivares e tireoide. O envolvimento da traqueia é extremamente raro.

RELATO DE CASO: Relato de caso raro de linfoma TLAM de traqueia, em mulher de 71 anos com tosse, dispneia, rouquidão e emagrecimento há um ano. Detectou-se lesão infiltrativa na porção média da traquéia. O diagnóstico anatomopatológico só foi obtido na biópsia do quinto procedimento endoscópico. A imunoquimioterapia R-COP (rituximabe, ciclofosfamida, vincristina e prednisona) induziu remissão completa dos sintomas e da lesão endoscópica.

CONCLUSÕES: Linfoma TLAM de traqueia é uma doença indolente e extremamente rara, que deve ser considerada no diagnóstico diferencial das lesões de vias aéreas. O diagnóstico anatomopatológico por um patologista experimentado é fundamental. Imunoquimioterapia com R-COP levou à remissão completa da doença.

\section{INTRODUCTION}

Mucosa-associated lymphoid tissue (MALT) lymphomas are most commonly found in the stomach, lungs, orbital soft tissue, salivary glands and thyroid. Cases affecting the conjunctiva, breasts, kidney, skin, liver and prostate, and some involving bone marrow have been reported. ${ }^{1}$ Involvement of the trachea is extremely rare, with only fourteen cases found in the literature through a PubMed search with no time limit'-15 (Table 1).

This report describes a rare case of MALT lymphoma of the trachea in a 71-year-old woman who presented with a one-year history of coughing, dyspnea, hoarseness and weight loss. The diagnosis was made only on the fifth biopsy attempt, by means of bronchoscopy. Immunochemotherapy consisting of rituximab, cyclophosphamide, vincristine and prednisone (R-COP) induced complete remission of symptoms and the endoscopic lesion.

\section{CASE REPORT}

A 71-year-old white woman presented with a one-year history of dry coughing, progressive dyspnea, $5 \mathrm{~kg}$ weight loss, nocturnal diaphoresis and six months of neck discomfort and hoarseness. 
She had a previous medical history of hypertension, which was under treatment with amlodipine ( $5 \mathrm{mg}$ daily), and hypothyroidism treated with levothyroxine ( $50 \mathrm{mcg}$ daily). She had had an episode of pneumonia, treated five years earlier. She had never smoked. She was anxious but looked well.

On physical examination, she presented reduced breathing sounds in both lungs, without any other remarkable finding. Renal and liver function tests, hemogram and lactic dehydrogenase levels were normal. Her beta 2 microglobulin level was $1.5 \mathrm{mg} / \mathrm{l}$ (upper limit of normal values: $1.31 \mathrm{mg} / \mathrm{l}$ ). Chest $\mathrm{x}$-ray showed a slight tracheal deviation, and lung function tests showed a mild obstructive picture. Bronchodilators and corticosteroids only attenuated the symptoms. Computed tomography (CT) of the chest (Figure 1) showed irregularities and narrowing of the mid-trachea. Bronchoscopy showed a friable infiltrative lesion involving all the walls of the trachea, starting $4 \mathrm{~cm}$ from the vocal cords and extending for $5 \mathrm{~cm}$ towards the carina, and stopping $2 \mathrm{~cm}$ away from it.

The initial biopsy showed reactional lymphoid hyperplasia. Only after the fifth endoscopic procedure with biopsies was the anatomopathological diagnosis made. The morphological and immunohistochemical features confirmed the presence of a low-grade non-Hodgkin's B-cell lymphoma with plasmacytic differentiation, suggestive of MALT lymphoma. The immunohistochemical panel revealed that the lymphoma cells were positive for CD20, lambda and, rarely, CD138 and negative for CD43, cyclina and CD5 (Figure 2). A bone marrow biopsy was normal.

Treatment consisting of rituximab $\left(375 \mathrm{mg} / \mathrm{m}^{2}\right.$ once a week for four weeks) and prednisone (20 $\mathrm{mg}$ /day) was ineffective with no clinical response and worsening of the symptoms. R-COP immunochemotherapy was then started with the following doses: rituximab $375 \mathrm{mg} / \mathrm{m}^{2}$, cyclophosphamide $750 \mathrm{mg} / \mathrm{m}^{2}$, vincristine
$2 \mathrm{mg}$ and prednisone $100 \mathrm{mg} / \mathrm{m}^{2}$ for five days every month. Herpes zoster and vincristine neuropathy developed as complications. The herpes was treated using acyclovir and the neuropathy improved after vincristine was withdrawn in the second cycle.

Table 1. Results from our review of the medical databases. Date of search: April 12, 2011

\begin{tabular}{|c|c|c|}
\hline Database & Search strategy & Results \\
\hline PubMed & $\begin{array}{l}\text { Lymphoma B cell marginal zone OR mucosa- } \\
\text { associated lymphoid tissue OR MALT AND } \\
\text { tracheal OR trachea }\end{array}$ & $\begin{array}{l}14 \text { case } \\
\text { reports }^{2-15}\end{array}$ \\
\hline Embase & $\begin{array}{l}\text { Lymphoma B cell marginal zone OR mucosa- } \\
\text { associated lymphoid tissue OR MALT AND } \\
\text { tracheal OR trachea }\end{array}$ & $\begin{array}{c}5 \text { case } \\
\text { reports }^{3,9-11,15}\end{array}$ \\
\hline
\end{tabular}

Using the same search strategies in the Cochrane Library, SciELO and Lilacs databases, no results were found.

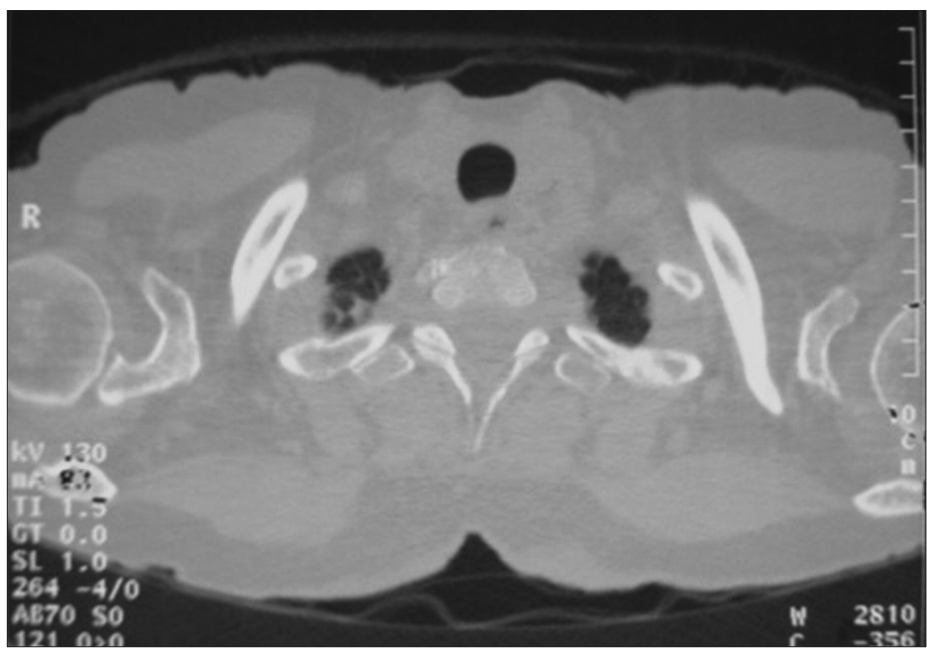

Figure 1. Tomography of the thorax showing irregularities and narrowing of the mid-trachea (arrow).

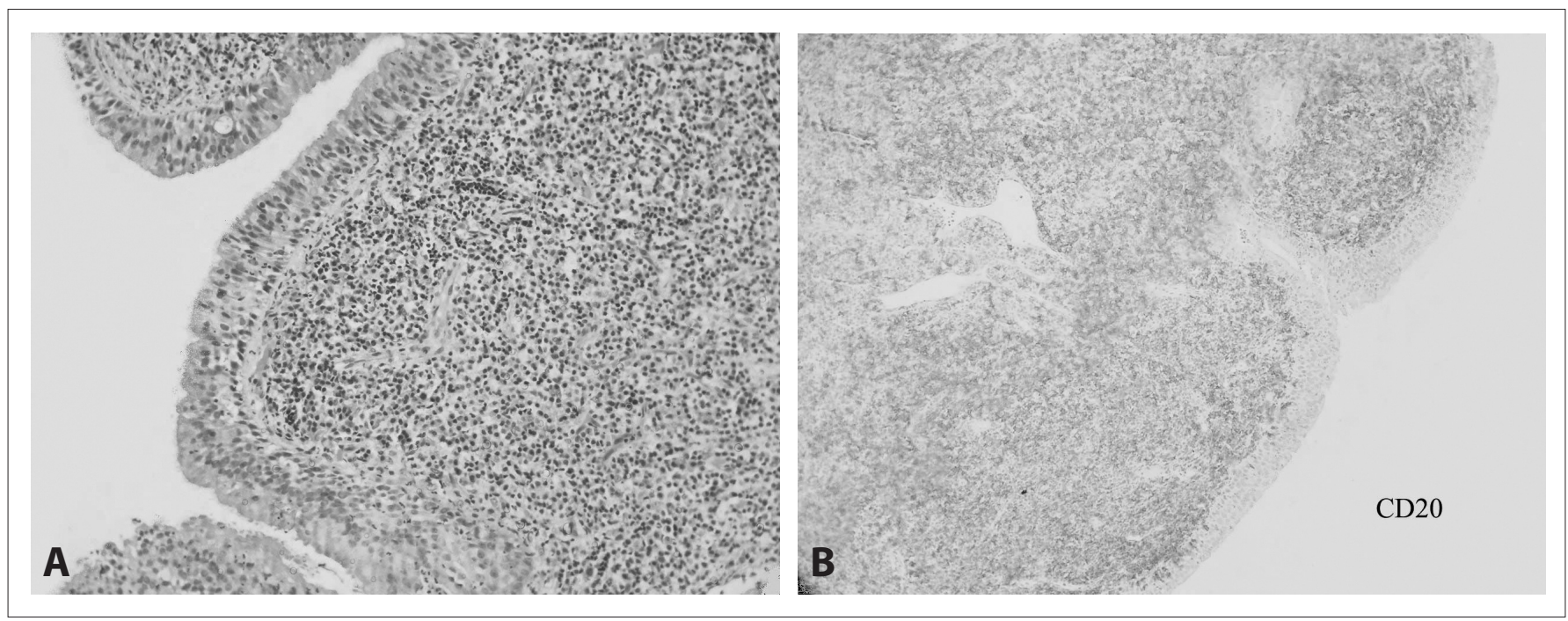

Figure 2. Photomicrograph of the tracheal wall. Panel A: showing heavy infiltration by lymphoma cells, consisting of small to mediumsized lymphocytes with plasmacytic differentiation and lymphoepithelial lesions. Panel B: immunohistochemical staining for CD20 demonstrating diffuse infiltration of B cells in the chorion of the tracheal wall. 
Bronchoscopy after the seventh cycle showed only a scar lesion, and this was confirmed in an anatomopathological sample. Eight cycles were completed with complete remission of symptoms.

\section{DISCUSSION}

Primary tumors of the trachea are rare; squamous cell carcinoma and adenoid cystic carcinoma make up $75 \%$ of such cases. ${ }^{2,3}$ Hematopoietic tumors are rare and principally comprise plasmocytoma and non-Hodgkin's lymphoma. The differential diagnoses for tracheal pathological conditions also include tuberculosis and fungal infections.

MALT consists of specialized lymphoid tissue protecting permeable mucosal sites that are in direct contact with the external environment. However, MALT lymphoma only occasionally occurs in places where this tissue is normally present, as seen in the tonsils and Peyer's patches. It generally arises through acquisition as a result of some preexisting disorder. Examples are Helicobacter pylori colonization in the stomach, autoimmune disease in the salivary gland (Sjögren's disease) and Hashimoto's thyroiditis.

The rarity of MALT lymphoma of the trachea is possibly due to the paucity of lymphoid tissue in this region. Kutta et al. ${ }^{16}$ studied 87 autopsies of the larynx in patients who were free from other diseases that might have affected laryngeal function. MALT was observed in the supraglottic region in $100 \%$ of the children, $90 \%$ or more of the adolescents, and $7.1 \%$ of individuals in their sixth decade. MALT was completely absent from the subglottis in all age groups. It is presumed that MALT occurs in the trachea in response to an antigenic stimulus, such as from bacterial or fungal infections and allergic reactions, but no antigens have been identified. ${ }^{4,16}$ MALT lymphomas are mainly located in the supraglottic and glottic areas, with only one reported case in the subglottic region. ${ }^{9}$

The clinical picture is similar to that of chronic obstructive pulmonary disease, which often delays the diagnosis. Our patient received treatment for asthma with minimal improvement in symptoms, probably due to steroids. Bronchoscopy and biopsy are essential. Most cases present with a polypoid lesion. In our case, there was some difficulty in obtaining a sample that would be satisfactory for the anatomopathological analysis. Only in the fifthbronchoscopy was enough material obtained. The same problem has been described in another problematic case, ${ }^{3}$ and such occurrences may represent a characteristic of the disease. The possibility that treatment can be implemented reinforces the need to obtain an anatomopathological diagnosis.

At presentation, MALT lymphoma is generally localized. The course tends to be indolent and the prognosis is good. ${ }^{2,4}$ In a series of 75 cases of non-gastrointestinal MALT lymphoma, there was complete remission in $79 \%$ and partial remission in $21 \%$. The best results were found for thyroid and tear duct tumors, while skin tumors were least responsive. ${ }^{1}$

There are no clear guidelines for the treatment of MALT lymphoma, with different therapeutic options depending on the site. ${ }^{13}$ When located in the trachea, a diversity of treatments have been shown to be effective: surgical resection, radiotherapy, bronchoscopic therapy, chemotherapy, immunotherapy (rituximab) and immunochemotherapy. ${ }^{1-15}$ The treatment can be done in combination or separately. Antibiotic therapy is not indicated, since no antigens like Helicobacter pylori are implicated in the pathophysiology.

\section{CONCLUSION}

MALT lymphoma of the trachea is an extremely rare and indolent disease. It has to be considered in the differential diagnosis of airway lesions. It is crucial to obtain an anatomopathological diagnosis from a specialized pathologist.

\section{REFERENCES}

1. Zinzani PL, Magagnoli M, Galieni P, et al. Nongastrointestinal low grade mucosa-associated lymphoid tissue lymphoma: analysis of 75 patients. J Clin Oncol. 1999;17(4):1254.

2. Kaplan MA, Pettit CL, Zukerberg LR, Harris NL. Primary lymphoma of the trachea with morphologic and immunophenotypic characteristics of low-grade B-cell lymphoma of mucosa-associated lymphoid tissue. Am J Surg Pathol. 1992;16(1):71-5

3. Okubo K, Miyamoto N, Komaki C. Primary mucosa-associated lymphoid tissue (MALT) lymphoma of the trachea: a case of surgical resection and long term survival. Thorax. 2005;60(1):82-3.

4. Lie CH, Liu SF, Wang JL, Wang MC, Lin MC. Primary endobronchia mucosa-associated lymphoid tissue lymphoma presenting with hemoptysis: A case report. Chest Medicine On-Line. Available from: http://www.priory.com/cmol/malt.pdf. Accessed in 2011 (Jun 27).

5. Wiggins J, Sheffield E, Green M. Primary B cell malignant lymphoma of the trachea. Thorax. 1988;43(6):497-8.

6. Schumann C, Lepper PM, Barth TF, Möller P, Krüger S. Successful immediate cryorecanalization of a simultaneous high-grade tracheal and bronchial stenosis as rare manifestations of bronchialassociated lymphoid tissue lymphoma. J Thorac Cardiovasc Surg 2009;137(1):e17-9

7. Kang JY, Park HJ, Lee KY, et al. Extranodal marginal zone lymphoma occurring along the trachea and central airway. Yonsei Med J. 2008;49(5):860-3.

8. García-García J, López García F, Carratalá Torregrosa JA, Huertas Valero E. Linfoma MALT traqueal: primer caso en España [Tracheal MALT Iymphoma: first case report from Spain]. Med Clin (Barc). 2008;131(12):478-9.

9. Andratschke M, Stelter K, Ihrler S, Hagedorn H. Subglottic tracheal stenosis as primary manifestation of a marginal zone B-cell lymphoma of the larynx. In Vivo. 2005;19(3):547-50 
10. Suzuki T, Akizawa T, Suzuki $H$, et al. Primary tracheal mucosaassociated lymphoid tissue lymphoma accompanying lung cancer. Common tumorigenesis or coincidental coexistence? Jpn J Thorac Cardiovasc Surg. 2000;48(12):817-9.

11. Tsurutani J, Kinoshita A, Kaida H, et al. Bronchoscopic therapy for mucosa-associated lymphoid tissue lymphoma of the trachea. Intern Med. 1999;38(3):276-8.

12. Arbib F, Gressin R, Blanc-Jouvan F, et al. Lymphome trachéal primitif de type MALT traité par laser YAG puis radiothérapie [Primary tracheal MALT lymphoma treated by YAG laser, then by radiotherapy]. Presse Med. 1994;23(23):1092-3.

13. Kobayashi H, Nemoto Y, Namiki K, Nakazawa K, Mukai M. Primary malignant lymphoma of the trachea and subglottic region. Intern Med. 1992;31(5):655-8.

14. Wiggins J, Sheffield E, Green M. Primary B cell malignant lymphoma of the trachea. Thorax. 1988;43(6):497-8.

15. Luick ML, Hansen EK, Greenberg MS, et al. Primary tracheal nonHodgkin's lymphoma. J Clin Oncol. 2011;29(8):e193-5.

16. Kutta H, Steven P, Tillmann BN, Tsokos M, Paulsen FP. Region-specific immunological response of the different laryngeal compartments: significance of larynx-associated lymphoid tissue. Cell Tissue Res. 2003;311(3):365-71.

\section{Sources of funding: None}

Conflict of interest: None

Date of first submission: September 15, 2008

Last received: July 10, 2011

Accepted: July 11, 2011

\section{Address for correspondence:}

Maria Elisa Ruffolo Magliari

Diretoria do Departamento de Medicina (DM)

Santa Casa de Misericórdia de São Paulo

Rua Dr. Cesáreo Motta Jr, 112

São Paulo (SP) — Brasil

CEP 01221-020

Tel. (+55 11) 2176-7300

Fax. (+55 11) 3097-0300

E-mail: elisamagliari@hotmail.com 